\title{
ANALISIS POLA KEMITRAAN PEMBENIHAN JAGUNG PT BISI INTERNATIONAL TbK DENGAN PETANI TERHADAP PENDAPATAN USAHATANI JAGUNG DI KABUPATEN SITUBONDO
}

\author{
Achmad Hafid1), Yohanes Nangameka ${ }^{2 *}$ ) \\ Fakultas Pertanian, Universitas Abdurachman Saleh Situbondo \\ *Email Korespondensi : comodo.consultan@yahoo.co.id
}

\begin{abstract}
Peluang untuk meningkatkan produksi jagung dapat dilakukan melalui perluasan area budidaya dan peningkatan produktivitas. Salah satu cara untuk meningkatkan produktivitas adalah kebutuhan untuk meningkatkan atau meningkatkan varietas unggul. Peningkatan vaarietas tanaman jagung dapat dicapai melalui program pemuliaan tanaman yang bertujuan untuk membentuk kultivar unggul, baik kultivar bebas dan hibrida. Varietas jagung hibrida telah terbukti memberikan hasil yang lebih baik dari varietas jagung jarak bebas. Secara umum, varietas hibrida lebih seragam dan mampu menghasilkan hasil 15-20\% lebih tinggi dari varietas bebas. Pembenihan jagung hibrida adalah salah satu solusi dalam meningkatkan produktivitas jagung. Benih jagung hibrida berpotensi memiliki hasil tinggi, umumnya lebih tahan terhadap penyakit, lebih responsif terhadap pemupukan, tanam dan tongkol lebih seragam. Sistem kemitraan yang dijalankan antara PT Bisi International Tbk dan petani jagung hibrida adalah sistem kemitraan dengan pola inti-plasma. Kemitraan ini berfokus pada prinsip saling membutuhkan, saling memperkuat dan saling menguntungkan dengan tujuan meningkatkan pendapatan. Faktor-faktor yang mempengaruhi pendapatan mitra bisnis jagung PT Bisi International Tbk di Kabupaten Situbondo adalah variabel biaya produksi, umur petani, pendidikan petani, luas lahan, dan pengalaman bermitra.
\end{abstract}

Kata Kunci: Kemitraan, Hatchery Jagung Hibrida, Kabupaten Situbondo

\begin{abstract}
Opportunities to increase corn production can be done through the expansion of cultivation area and increase productivity. One way to increase productivity is the need to improve or improve the superior varieties. Improvement of corn plant vaarietas can be reached through plant breeding program that aims to form a superior cultivar, both free cultivars and hybrids. Hybrid corn varieties have been shown to provide better results from free-ranged maize varieties. In general, hybrid varieties are more uniform and capable of producing 15$20 \%$ higher yields of free varieties. Hybrid corn hatchery is one of the solutions in increasing corn productivity. Hybrid corn seeds potentially have high yields, are generally more resistant to disease, more responsive to fertilization, cropping and cobs are more uniform. The partnership system run between PT Bisi International Tbk and hybrid corn farmers is a partnership system with a core-plasma pattern. This partnership focuses on the principle of mutual need, mutual strengthening and mutual benefit with the aim of increasing revenue. Factors that influence the income of corn business partner PT Bisi International Tbk in Situbondo Regency are variable of production cost, farmer age, farmer education, land area, and experience partnered.
\end{abstract}

Key Word: Partnership, Hybrid Corn Hatchery, Situbondo District 


\section{PENDAHULUAN}

Pertanian adalah suatu jenis kegiatan produksi yang berlandaskan proses pertumbuhan dari tumbuh-tumbuhan dan hewan. Pertanian dalam arti sempit dinamakan pertanian rakyat sedangkan pertanian luas meliputi pertanian dalam arti sempit, kehutanan, peterakan perkebunan dan perikanan.Secara garis besar, pengertian pertanian dapat diringkas menjadi empat komponen yang tidak terpisahkan. Keempat komponen tersebut meliputi: (1) proses produksi, (2) petani atau pengusaha pertanian, (3) tanah tempat usaha, dan (4) usaha pertanian (Soetriono. dkk, 2006)

Jagung adalah komoditas penting untuk pangan dan pakan. Pengusahaan jagung di dunia lebih dari 120 juta ha lahan kering dan Indonesia merupakan salah satu tempat pengusahaan jagung utama di dunia.

Selain pada lahan kering, jagung diusahakan pada lahan sawah setelah panen padi dengan produktivitas mencapai sekitar 7 ton/ha (Puslitbangtan, 2006).

Periode 1969- 2015 pertumbuhan luas panen jagung di Pulau Jawa dan Luar Pulau Jawa hampir sama, masing-masing sebesar2,56\% dan 2,78\%. Sebaliknya pada rentang periode waktunya 10 tahunterakhir yaitu antara tahun 2005 - 2015 pertumbuhan luas panen jagungdi Luar Jawa lebih tinggi dari pada di Jawa, pertumbuhan luas panen diLuar Jawa 2,84\% sedangkan Jawa 0,82\%. Rendahnya pertumbuhan luaspanen jagung di Jawa karena lahan untuk tanaman jagung harusbersaing dengan komoditas lain yang memiliki nilai ekonomi lebih tinggiatau sebagai bahan pangan utama seperti padi sawah, komoditasperkebunan, hortikultura atau komoditas tanaman semusim lainnya. Sebaliknya, tingginya pertumbuhan luas panen di Luar Jawa ini antara lain karena daya saing produksi jagung yang relatif lebih baik pada lahan sawah tadah hujan dan lahan kering dibandingkan dengan daya saing komoditas lain (Deptan, 2015).

Peluang peningkatan produksi jagung dapat dilakukan melalui perluasan areal pertanaman dan peningkatan produktivitas. Salah satu cara untuk meningkatkan produktivitas adalah perlu dilakukan perbaikan atau perbaikan varietas unggul. Perbaikan vaarietas tanaman jagung dapat ditempuh melaului program pemuliaan tanaman yang bertujuan untuk membentuk kultivar unggul, baik kultivar bebas maupun hibrida. Varietas jagung hibrida telah terbukti memberikan hasil yang lebih baik dari varietas jagung bersari bebas. Secara umum, varietas hibrida lebih seragam dan mampu berproduksi lebih tinggi 15-20\% dari varietas bersari bebas (morris, 1995)

Pembenihan jagung hibrida merupakan salah satu solusi dalam peningkatan produktivitas jagung. Benih jagung hibrida berpotensi memiliki daya hasil tinggi, umumnya lebih tahan terhadap penyakit, lebih tanggap terhadap pemupukan, pertanaman dan tongkol lebih seragam (Iriany dan Takdir, 2007)

Menurut Undang-undang nomor 9 tahun1995 merupakan suatu kerjasama antara usaha kecil dengan usaha menengah atau dengan usaha besar disertai pembinaan dan pengembangan yang berkelanjutan oleh usaha menengah atau usaha besar dengan memperhatikan prinsip saling membutuhkan, saling memperkuat, dan saling menguntungkan dengan tujuan meningkatkan pendapatan, kesenimbungan usaha, peningkatan skala usaha serta menumbuhkan dan meningkatkan kemmpuan usaha kelompok usaha mandiri (Soemardjo et al, 2004).

PT Bisi International Tbk merupakan salah satu perusahaan di Indonesia yang bergerak dibidang agribisnis dalam pembenihan jagung hibrida. PT Bisi Interntional Tbk dalam membenihkan jagung hibrida menjalin sebuah kerjasama dengan petani karena perusahaan membutuhkan lahan yang luas dan jaminan atas pasokan bahan baku secara kontiyu untuk kebutuhan produksi perusahaan.

Hasil yang diharapkan dari pelaksanaan kemitraan ini yaitu dapat meningkatkan pendapatan petani, menambah pengetahuan bagi para petani dan memberikan jaminan 
pasar yang pasti untuk hasil produksi yang diusahakan. Bagi perusahaan diharapkan dapat memenuhi permintaan pasar. Informasi pasar dan kepastian pasar melalui kemitraan antara petani dengan perusahaan sangat penting untuk memperoleh kepastian harga, kualitas dan kuantitas produk yang diinginkan oleh perusahaan.

Kabupaten Situbondo adalah salah satu Kabupaten di Propinsi Jawa Timur yang memiliki potensi akan usahatani jagung. Produksi jagung pada tahun 2017 yaitu sebesar 289.932 Ton dengan luas lahan 58.886 Ha (BPS Kab.Situbondo, 2017). Kabupaten Situbondo terdiri dari 17 Kecamatan, tujuh Kecamatan tersebut diatas merupakan wilayah Kecamatan yang yang bermitra dengan PT Bisi International Tbk. Bagi yang bermitra petani mendapatkan bantuan benih, pinjaman pupuk dan obat-obatan. Namun program ini kebanyakan petani trauma terhadap pembenihan jagung karena sebelumnya pernah bermitra dengan perusahaan lain, akan tetapi mitra tersebut mengalami kerugian sehingga petani tidak mau lagi menanam jagung pembenihan atau yang sering disebut oleh masyarakat yaitu jagung jantan-betina.

Berdasarkan latar belakang tersebut, maka peneliti tertarik untuk melakukan penelitian ini agar dapat mengubah sudut pandang petani terhadap jagung pembenihan. Penelitian ini meliputi pola kemitraan, pendapatan petani jagung, efisiensi biaya, dan faktor-faktor yang mempengaruhi tingkat pendapatan petani jagung yang menjalin kemitraan dengan PT Bisi International Tbk.Penelitian ini dilakukan di Kabupaten Situbondo.

Berdasarkan penjelasan yang telah dipaparkan diatas, maka dapat diidentifikasikan rumusan masalah sebagai berikut : 1) Bagaimana pendapatan petani jagung yang melakukan kemitraan dengan PT Bisi International Tbk di Kabupaten Situbondo ? 2) Faktor - faktor apa saja yang berpengaruh terhadap tingkat pendapatan petani jagung yang melakukan kemitraan dengan PT Bisi International Tbk di Kabupaten Situbondo?

\section{METODE PENELITIAN}

Metode deskriptif yaitu suatu metode dalam meneliti status sekelompok manusia, suatu objek, suatu set kondisi, suatu sistem pemikiran ataupun suatu kelas peristiwa pada masa sekarang. Metode tersebut bertujuan untuk membuat deskripsi, gambaran atau lukisan secara sitematis, faktual dan akurat mengenai fakta daerah tertentu. Teknik pengumpulan data melalui kegiatan: dokumentasi, wawancara, dan observasi. Teknik analisis data menggunakan regresi linear berganda.

\section{HASIL DAN PEMBAHASAN}

\section{Pendapatan Petani jagung yang Melakukan Kemitraan dengan PT Bisi International Tbk di Kabupaten Situbondo yaitu Menguntungkan Petani}

Pada dasarnya kemitraan merupakan suatu kerjasama antara dua belah pihak atau lebih yang disertai dengan pembinaan, pengawasan dan pengembangan dengan memperhatikan prinsip saling memerlukan, saling memperkuat, dan saling menguntungkan. Tujuan dari kemitraan tersebut adalah memberikan dampak positif terhadap pihak yang bermitra diantaranya meningkatkan pendapatan dan meningkatkan kualitas sumber daya kelompok mitra. Kemitraan antara petani jagung dengan PT Bisi International Tbk di Kabupaten Situbondo merupakan salah satu kerjasama yang terjalin antara petani jagung dengan PT Bisi International Tbk yang menerapkan prinsip saling memerlukan, saling memperkuat, dan saling menguntungkan. Kemitraan tersebut secara tidak langsung akan berdampak kepada pendapatan petani, karena petani jagung di Kabupaten Situbondo diberikan bimbingan selama budidaya hingga panen dengan tujuan jagung yang dihasilkan berkualitas baik, lulus sertifikasih benih dan produksinya lumayan tinggi, sehingga dengan produksi yang tinggi dan layak dijadikan benih maka pendapatan 
petani juga akan tinggi. Analisis usahatani yang dilakukan adalah bertujuan untuk mengetahui seberapa besar pendapatan yang diterima oleh petani jagung mitra usaha di Kabupaten Situbondo pada musim tanam tahun 2017. Pendapatan yang diterima oleh petani berasal dari besarnya penerimaan dikurangi dengan biaya yang dikeluarkan oleh petani dalam mengusahakan jagung. Hasil perhitungan pendapatan usahatani jagung pembenihan di Kabupaten Situbondo dapat dilihat pada tabel 5.4 untuk menguji hipotesis pertama sebagai berikut:

Tabel 1.Pendapatan Usahatani jagung pembenihan di Kabupaten Situbondo

\begin{tabular}{clc}
\hline No & \multicolumn{1}{c}{ Uraian } & Nilai \\
\hline 1 & Rata-rata produksi benih & $2.747 \mathrm{Kg}$ \\
2 & Rata-rata penerimaan & $\mathrm{Rp} \mathrm{6.867.813}$ \\
3 & Rata-rata biaya produksi & $\mathrm{Rp} \mathrm{4.205.038}$ \\
\hline 4 & Rata-rata Pendapatan & $\mathrm{Rp} \mathrm{2.662.775}$ \\
5 & Rata-rata R/C ratio & 1,6 \\
\hline
\end{tabular}

Sumber : Data diolah tahun 2018

Berdasarkan tabel diatas bahwa rata-rata produksi benih sebanyak $2.747 \mathrm{Kg} / \mathrm{Ha}$. Total biaya rata-rata yang dikeluarkan per Hektare oleh petani dalam satu kali proses budidaya jagung pembenihan adalah sebesar Rp 4.205.038. Biaya usahatani yang dikeluarkan oleh petani tersebut berasal dari biaya variabel dan biaya tetap. Biaya variabel yang dikeluarkan petani antara lain biaya tenaga kerja, biaya pupuk seperti pupuk Urea, Phonzka, dan ZA. Biaya variabel lain yang harus dikeluarkan oleh petani yaitu obat-obatan seperti Paket Anti Gulma (PAG), Furadan dan MKP. Sedangkan biaya tetap yang dikeluarkan oleh petani yaitu biaya pengairan dan biaya pajak untuk lahan milik sendiri.

Berdasarkan hasil perhitungan, rata-rata pendapatan petani jagung mitra usaha di Kabupaten Situbondo adalah sebesar Rp 2.662.775 per Ha. Pendapatan petani tersebut berasal dari penerimaan dikurangi dengan biaya produksi yang dikeluarkan oleh petani. Besarnya pendapatan yang diterima oleh petani ini cukup memberikan keuntungan bagi petani. Hal tersebut juga dapat dilihat dari nilai $\mathrm{R} / \mathrm{C}$ ratio usahatani jagung yaitu lebih besar dari satu. Rata-rata nilai $\mathrm{R} / \mathrm{C}$ ratio untuk masing masing petani jagung adalah 1,6. Nilai R/C ratio sebesar 1,6 dapat diartikan bahwa dengan menggunakan biaya produksi sebesar Rp. 1,- akan diperoleh penerimaan sebesar Rp. 1,6,- sehingga pendapatan bersih yang diperoleh adalah sebesar Rp. 0,6,-. Dengan hasil tersebut maka dapat dikatakan tingkat pendapatan petani jagung cukup tinggi karena keuntungan yang diperoleh satu dari biaya produksi yang dikeluarkan. Selama proses budidaya hingga panen petani diberikan bimbingan dan selalu dipantau oleh petugas, sehingga apabila terdapat gangguan/serangan hama pada tanaman jagung akan segera dapat diatasi, dengan begitu kualitas jagung dan hasil produksi dari tanaman jagung cukup bagus dan lulus sertifikasi benih sehingga tingkat pendapatan petani cukup tinggi.

Faktor-faktor yang Mempengaruhi Tingkat Pendapatan Petani di Kabupaten Situbondo yaitu Biaya Produksi, Umur Petani, Tingkat Pendidikan Petani, Luas Lahan, dan Pengalaman

Pengujian faktor-faktor yang berpengaruh terhadap pendapatan petani tersebut menggunakan model fungsi linier berganda sebagai berikut:

$\mathrm{Y}=-4.641 .037,042+1,270 \mathrm{X} 1-54.835,517 \mathrm{X} 2+126.007,026 \mathrm{X} 3-1.094 .858,359 \mathrm{X} 4+$ 132097,012 X5 
Apabila variabel X1, X2, X3, X4, dan X5 bernilai 0 maka pendapatan (Y) akan bernilai negatif (-) dapat diartikan bahwa petani mengalami kerugian sehingga variabel bebas atau independen sangat memberikan pengaruh terhadap variabel terikat atau dependen.

Tabel 2. Analisis Varian (ANOVA) Faktor Faktor yang Berpengaruh Terhadap Pendapatan Petani Jagung Mitra Usaha di Kabupaten Situbondo

\begin{tabular}{|c|c|c|c|c|c|c|}
\hline \multicolumn{7}{|c|}{ ANOVA $^{a}$} \\
\hline & & Sum of Squares & Df & Mean Square & $\mathrm{F}$ & Sig. \\
\hline \multirow[t]{3}{*}{1} & Regression & 1307112820111185,5 & 5 & 261422564022237,100 & 80,878 &, $000^{\mathrm{b}}$ \\
\hline & Residual & $\begin{array}{r}200402083576314,25 \\
0\end{array}$ & 62 & 3232291670585,714 & & \\
\hline & Total & $\begin{array}{r}1507514903687499,8 \\
00\end{array}$ & 67 & & & \\
\hline
\end{tabular}

a. Dependent Variable: Pendapatan

b. Predictors: (Constant), Pengalaman Mitra, Umur, Luas Lahan, Pendidikan, Biaya Produksi

Berdasarkan Tabel 2 diatas Pengujian dengan uji $\mathrm{F}$ bertujuan untuk melihat keseluruhan variabel bebas memberikan pengaruh pada variabel terikat. Hasil analisis pada tabel 5.6 diperoleh nilai F-hitung sebesar 80,878 lebih besar dari F-tabel sebesar 2,36 pada taraf kepercayaan 95\%. Hasil tersebut menunjukkan bahwa secara bersama sama variabel bebas (biaya produksi, umur petani, pendidikan petani, luas lahan dan pengalaman bermitra) sangat berpengaruh terhadap pendapatan petani sebagai variabel terikat.

Besarnya parameter faktor-faktor yang berpengaruh terhadap pendapatan petani jagung dapat diketahui melalui nilai determinasi (R2). Koefisien determinasi berfungsi untuk mengetahui berapa persen pengaruh yang diberikan variabel $X$ secara simultan terhadap variabel Y. Berikut ini merupakan nilai determinasi (R2) dapat diliat pada Tabel 5.6.

Tabel 3. Nilai determinasi (R2) Model Summary

\begin{tabular}{lcrcc}
\hline Model & $\mathrm{R}$ & R Square & $\begin{array}{c}\text { Adjusted R } \\
\text { Square }\end{array}$ & Std. Error of the Estimate \\
\hline 1 &, $931^{\text {a }}$ &, 867 &, 856 & 1797857,52233 \\
\hline \multicolumn{2}{l}{ a. Predictors: (Constant), Pengalaman Mitra, Umur, Luas Lahan, Pendidikan, Biaya Produksi }
\end{tabular}

Berdasarkan output pada tabel Tabel 3 menunjukkan nilai Adjust $\mathrm{R}$ square sebesar 0,856, hal ini mengandung arti bahwa pengaruh variabel X1, X2, X3, X4, dan X5 secara simultan terhadap variabel $Y$ adalah sebesar $85,6 \%$. Pendapatan usahtani jagung mitra usaha di Kabupaten Situbondo dipengaruhi oleh variabel bebas yaitu variabel biaya produksi, umur petani, pendidikan petani, luas lahan, dan pengalaman bermitra sebesar $85,6 \%$, sedangkan sisanya sebesar $14,4 \%$ dipengaruhi oleh variabel-variabel lain yang tidak dimasukkan dalam model regresi.

Untuk mengetahui seberapa besar pengaruh dari masing-masing variabel bebas terhadap tingkat pendapatan petani jagung mitra usaha di Kabupaten Situbondo dlakukan dengan uji t dimana hasil dari analisis regresi linear berganda dapat diliat dari Tabel 3. 
Tabel 4. Analisis Regresi Linear Berganda Terhadap Faktor-Faktor Yang Mempengaruhi Pendapatan Petani Jagung Mitra Usaha di Kabupaten Situbondo

Coefficients $^{\mathrm{a}}$

\begin{tabular}{|c|c|c|c|c|c|}
\hline \multirow[b]{2}{*}{ Model } & \multicolumn{2}{|c|}{ Unstandardized Coefficients } & \multirow{2}{*}{$\begin{array}{c}\text { Standardized } \\
\text { Coefficients }\end{array}$} & \multirow[b]{2}{*}{$\mathrm{T}$} & \multirow[b]{2}{*}{ Sig. } \\
\hline & $\mathrm{B}$ & Std. Error & & & \\
\hline 1 (Constant) & $-4641037,042$ & 2064285,376 & & $-2,248$ & 028 \\
\hline Biaya Produksi & 1,270 & ,253 & 1,131 & 5,029 &, 000 \\
\hline Umur & 54835,517 & 35205,101 & 089 & 1,558 & ,124 \\
\hline Pendidikan & 126007,026 & 76395,123 & 095 & 1,649 & 104 \\
\hline Luas Lahan & $-1094858,359$ & 971703,146 &,- 251 & $-1,127$ & ,264 \\
\hline $\begin{array}{l}\text { Pengalaman } \\
\text { Mitra }\end{array}$ & 132097,012 & 141280,907 & ,048 & ,935 & ,353 \\
\hline
\end{tabular}

Berdasarkan output pada tabel 5.8 diatas, dapat diketahui bahwa konstanta dari analisis tersebut sebesar -4.641.037,042artinya bahwa dalam mengusahakan Jagung pembenihan sebelum memperoleh penerimaan petani jagung sudah menanggung biaya sebesar Rp 4.641.037,042yang digunakan sebagai modal awal usahataninya.

Pengaruh variabel bebas (biaya produksi, umur petani, pendidikan petani, luas lahan, dan pengalaman bermitra) terhadap variabel terikat (pendapatan) dapat diliat pada Tabel 5.8 adalah sebagai berikut:

\section{Biaya Produksi (X1)}

Nilai koefisien regresi biaya produksi adalah sebesar Rp 1,270 yang artinya bahwa setiap peningkatan biaya produksi sebesar Rp 1, maka pendapatan petani meningkat sebesar Rp 1,270 dalam satu kali musim tanam, dengan asumsi faktor lainnya tetap. Hal tersebut diakibatkan karena penggunaan biaya oleh petani dalam memproduksi jagung pembenihan dilakukan dengan semaksimal mungkin. Contohnya yaitu penggunaan pupuk yang pas dan obat-obatan, hal tersebut dimaksudkan untuk memperoleh hasil produksi yang tinggi, kualitas jagung yang baik dan lulus sertifikasi benih sesuai dengan yang diinginkan pihak PT. Bisi International, Tbk. Pengolahan tanah dan obat herbisida dimaksudkan untuk memperoleh hasil produksi yang tinggi dan memperoleh kualitas yang baik.

Variabel biaya produksi mempengaruhi pendapatan secara simultan dengan variabel lainnya, secara parsial biaya produksi tidak dapat mempengaruhi pendapatan petani karena apabila variabel biaya produksi bernilai positif dan variabel lainnya bernilai 0 maka pendapatan akan bernilai negatif. Maka dari itu variabel X1, X2, X3, X4 dan X5 mempengaruhi pendapatan secara simultan sebesar $85,6 \%$.

\section{Umur Petani (X2)}

Nilai koefisien regresi umur petani adalah sebesar 54.835,517 yang artinya bahwa setiap peningkatan umur petani sebesar 1 tahun, maka akan menurunkan pendapatan petani jagung mitra usaha sebesar Rp 54.835,517 dengan asumsi bahwa faktor lainnya tetap. Hal tersebut diakibatkan karena petani jagung yang usianya lebih muda memiliki tenaga yang lebih segar dibandingkan dengan petani jagung yang usianya lebih tua, sehingga akan berpengaruh dalam melakukan usahatani jagung mitra usaha.

Variabel umur petani mempengaruhi pendapatan secara simultan dengan variabel lainnya, secara parsial umur petani tidak dapat mempengaruhi pendapatan petani karena apabila variabel umur petani bernilai positif dan variabel lainnya bernilai 0 maka 
pendapatan akan bernilai negatif. Maka dari itu variabel X1, X2, X3, X4 dan X5 mempengaruhi pendapatan secara simultan sebesar $85,6 \%$.

\section{Pendidikan Petani (X3)}

Nilai koefisien regresi pendidikan petani adalah sebesar $126.007,026$ yang artinya bahwa setiap peningkatan pendidikan petani sebesar 1 tahun, maka pendapatan petani jagung akan meningkat sebesar Rp 126.007,026 dengan asumsi bahwa faktor lainnya tetap. Hal tersebut dikarenakan petani yang memiliki pendidikan lebih tinggi memiliki tingkat kecerdasan dan lebih tanggap dalam mempelajari usahatani jagung pembenihan, sehingga petani yang pendidikannya lebih tinggi lebih mengetahui bagaimana cara mendapatkan hasil produksi yang maksimal.

Variabel pendidikan petani mempengaruhi pendapatan secara simultan dengan variabel lainnya, secara parsial pendidikan petani tidak dapat mempengaruhi pendapatan petani karena apabila variabel pendidikan petani bernilai positif dan variabel lainnya bernilai 0 maka pendapatan akan bernilai negatif. Maka dari itu variabel X1, X2, X3, X4 dan X5 mempengaruhi pendapatan secara simultan sebesar 85,6\%.

\section{Luas Lahan (X4)}

Nilai koefisien regresi luas lahan adalah sebesar $-1.094 .858,359$ yang artinya bahwa setiap peningkatan luas lahan sebesar $1 \mathrm{Ha}$, maka akan menurunkan pendapatan petani jagung mitra usaha sebesar Rp 1.094.858,359 dengan asumsi bahwa faktor lainnya tetap. Luas lahan yang besar akan berdampak bagi peningkatan pendapatan petani karena semakin besar luas lahan yang dimiliki akan lebih susah dalam melakukan perawatan budidaya jagung pembenihan, sehingga akan berdampak pada pendapatan petani.

Variabel luas lahan mempengaruhi pendapatan secara simultan dengan variabel lainnya, secara parsial luas lahan tidak dapat mempengaruhi pendapatan petani karena apabila variabel luas lahan bernilai positif dan variabel lainnya bernilai 0 maka pendapatan akan bernilai negatif. Maka dari itu variabel X1, X2, X3, X4 dan X5 mempengaruhi pendapatan secara simultan sebesar $85,6 \%$.

\section{Pengalaman Bermitra (X5)}

Nilai koefisien regresi lama bermitra adalah sebesar Rp 141.280,907 yang artinya bahwa setiap peningkatan pengalaman petani bermitra sebesar 1 tahun, maka akan meningkatkan pendapatan petani jagung sebesar Rp 141.280,907 dalam satu kali musim tanam, dengan asumsi faktor lainnya tetap. Hal tersebut dikarenakan petani jagung mitra yang lebih lama bermitra memiliki pengalaman yang lebih, sehingga petani yang lebih lama bermitra lebih mengetahui bagaimana cara memperoleh pendapatan yang maksimal.

Variabel pengalaman bermitra mempengaruhi pendapatan secara simultan dengan variabel lainnya, secara parsial pengalaman bermitra tidak dapat mempengaruhi pendapatan petani karena apabila variabel pengalaman bermitra bernilai positif dan variabel lainnya bernilai 0 maka pendapatan akan bernilai negatif. Maka dari itu variabel $\mathrm{X} 1, \mathrm{X} 2, \mathrm{X} 3$, X4 dan X5 mempengaruhi pendapatan secara simultan sebesar 85,6\%

\section{KESIMPULAN}

Bedasarkan hasil analis dan pembahasan, maka dapat diambil beberapa kesimpulan

Berdasarkan hasil analisis dan pembahasan, maka dapat diambil beberapa kesimpulan sebagai berikut:

1. Pendapatan rata-rata yang diterima oleh petani jagung mitra usaha di Kabupaten Situbondo adalah sebesar Rp 2.662.775 per Ha nilai tersebut menunjukkan keuntungan 
bagi petani. Analisis R/C rationya sebesar 1,6 berarti usahatani jagung pembenihan menguntungkan bagi petani

2. Faktor - Faktor yang mempengaruhi pendapatan usahtani jagung mitra usaha PT Bisi International Tbk di Kabupaten Situbondo yaitu variabel biaya produksi, umur petani, pendidikan petani, luas lahan, dan pengalaman bermitra sebesar 85,6\%, sedangkan sisanya sebesar 14,4\% dipengaruhi oleh variabel-variabel lain yang tidak dimasukkan dalam model regresi.

\section{REFERENSI}

Agustina, Imaniar. 2011. Prospek Pengembangan Program Kemitraan dan Faktor-Faktor yang Mempengaruhi Pendapatan Usahatani Benih Buncis Pada Program Kemitraan (Contract Farming). PT. Benih Citra Asia.Skripsi. Jember: Fakultas Pertanian Universitas Jember.

Augusty, Ferdinand. 2006. Metode Penelitian Manajemen. Semarang: Badan Penerbit Universitas Diponegoro. Bogor.

Departemen Pertanian. 2015. Rencana Strategis 2015-2019 Peraturan Mentri Pertanian. Jakarta.

Gumbira, S., 2001. Manajemen Agribisnis. Jakarta: PT. Ghalia Indonesia.

Hernanto, F. 1996. Ilmu Usahatani. Jakarta: Penebar Swadaya.

Hipi, A., B. T. R. Erawati, dan A.M. Takdir. 2006. Potensi Hasil Galur Harapan Jagung Hibrida pada Agroekosistem Lahan Kering di Lombok Timur. Diakses dari http://ntb.litbang.deptan.go.id/2006/THP/potensihasil.doc. Tanggal 23 Januari 2009.

Makkulawu, A. Takdir, Sri Sunarti, dan Made J. Mejaya. 2007. Pembentukan Varietas Jagung Hibrida. Dalam Jagung: Teknik Produksi danPengembangan. Pusat Penelitian dan Pengembangan Tanaman Pangan.Bogor.

Mejaya, M.J., M. Azrai dan R. Neni Iriany. 2007. Pembentukan Varietas Unggul Jagung Bersari Bebas. Dalam Jagung: Teknik Produksi danPengembangan.Pusat Penelitian dan Pengembangan Tanaman Pangan.Bogor.

Moh Nazir. 2003. Metode Penelitian. Jakarta : Ghalia Indonesia, 2003.

Puslitbangtan.2006. Pengembangan Jagung di Lahan Bera. Berita Puslitbangtan.

Siregar, Syofian. 2013. Statistik Parametrik untuk Penelitian Kuantitatif. Jakarta.

Soekartawi. 1995. Analisis Usahatani. Jakarta: UI-Press.

Soemardjo, dkk. 2004. Teori dan Praktek Kemitraan Agribisnis. Jakarta: Penebar Swadaya.

Soetriono, dkk. 2006. Pengantar Ilmu Pertanian. Malang: Banyumedia Publishing.

Sugiyono. 2011. Metode Penelitian Kuantitatif, Kualitatif dan R\&D. Bandung: Afabeta 
Sujarweni, V Wiratna dan Poly Endrayanto.(2012). Statistik untuk Penelitian.Yogyakarta : Graha Ilmu

Warisno. 2009. Jagung Hibrida. Yogyakarta. Kanisius.

Wibowo, R. 2000. Ekonometrika Analisis Data Parametrik.Jember: Fakultas Pertanian Universitas Jember. 